\title{
Health Academy Program: importance for users and funding difficulties
}

\author{
Programa Academia da Saúde: importância para os usuários e as dificuldades de \\ financiamento
}

\section{AUTHOR'S \\ Ana Mônica Serakides Ivo ${ }^{1,2}$ (D) \\ Vinícius Coimbra Viana ${ }^{2,3}$ (D) \\ Maria Imaculada de Fátima Freitas ${ }^{1}$ \\ 1 Universidade Federal de Minas Gerais, Escola de Enfermagem, Núcleo de Pesquisa e Estudos em Saúde Coletiva, Belo Horizonte, Minas Gerais, Brasil. \\ 2 Pontifícia Universidade Católica de Minas Gerais, Grupo de Estudos e Pesquisa em Avaliação e Promoção da Atividade Física, Belo Horizonte, Minas Gerais, Brasil. \\ 3 Prefeitura Municipal de Betim, Minas Gerais, Brasil.}

\section{CORRESPONDING}

Ana Mônica Serakides Ivo

amsivo@hotmail.com

Rua Paulista, n. 787. Belo Horizonte,

Minas Gerais, Brasil.

CEP: $31910-340$

DOI

$10.12820 /$ rbafs. $25 \mathrm{e} 0169$

\section{(cc) BY}

This work is licensed under a Creative Commons Attribution 4.0 International License.

\begin{abstract}
The Health Academy Program (PAS) is a public health promotion policy in primary care (PC) that has physical activity (PA) as one of its main axes. The Previne Brasil Program (PPB) established a new funding program for PC in 2019. The aim of this study was to understand the meaning of PA and PAS according to its users and to discuss the consequences of PPB in the structuring and functioning of the program. This is a qualitative approach study, supported by the theory of social representations. 33 in-depth interviews were performed on users from the Belo Horizonte PAS, interpreted by the Structural Narration Analysis. It was revealed that there are profound representations on PA as remedy for physical and psychosocial diseases and others, such as a contribution for the improvement of quality of life. Users see PAS as a necessary and inclusive health promotion policy, as it offers free access to quality PA, defined as one of the main aspects for joining it. The funding provided from the PPB does not include specific funding for team maintenance for the Extended Nucleus of Family Health in Primary Care, removing responsibility from the municipal managers to gather multiprofessional teams. The absence of these teams, which include physical education professionals who are responsible for $90 \%$ of the actions of the PAS, can compromise the outcomes recognized by the users of the program, especially those related to the reduction of inequalities of access and also the various actions to promote health within the PC.
\end{abstract}

Keywords: Health promotion, Public policies, Qualitative research, Collective health, Program evaluation RESUMO

O Programa Academia da Saúde (PAS) é uma política pública de promoção da saúde na Atenção Primária (AP) que tem a atividade fisica (AF) como um de seus eixos principais. Em 2019, o Programa Previne Brasil (PPB) estabeleceu um novo financiamento para AP. Objetivou-se, no estudo, compreender o significado da AF e do PAS, segundo os usuários para discutir as consequências do PPB na estruturação e funcionamento do Programa. Estudo de abordagem qualitativa, apoiado na teoria das representaçôes sociais. Foram realizadas 33 entrevistas em profundidade, com usuários do PAS de Belo Horizonte, interpretadas pela Análise Estrutural de Narração. A análise revelou que existem representaçôes profundas sobre a AF como um remédio para doenças físicas e psicossociais e outras em construção como a de contribuição à melhoria da qualidade de vida. Os usuários entendem o PAS como uma política de promoção da saúde necessária e inclusiva, por oferecer acesso gratuito $\grave{a} A F$ de qualidade, definidas como um dos principais aspectos para adesão. O financiamento previsto no $P P B$ não inclui o repasse financeiro especifico para manutenção das equipes do Núcleo Ampliado de Saúde da Familia na Atenção Básica (NASF-AB), desobrigando os gestores municipais a compor as equipes multiprofissionais. A ausência destas equipes, que incluem o profissional de educação física, responsável por $90 \%$ das ações dos PAS, pode comprometer os desfechos reconhecidos pelos usuários do Programa, principalmente os relacionados à redução das desigualdades de acesso, e comprometimento das diversas açôes de promoção da saúde no âmbito da AP.

Palavras-chave: Promoção da saúde; Políticas pública; Pesquisa qualitativa; Saúde coletiva; Avaliação de programas.

\section{Introduction}

The Health Academy Program (PAS) was created in 2011 to be a space for health promotion and care giving by means of promoting healthier lifestyles, and it is the broadest policy within the scope of public health promotion policies having physical activity $(\mathrm{PA})$ as one of its main axes ${ }^{1}$. Health promotion actions combining public policies and actions inside communities with the aim of improving the populations' health and quality of life are capable of developing individuals' autonomy, enhancing their own social and collective capacities, considering the different contexts in which they live ${ }^{2}$. Results for better health conditions for the population are expected, together with a better management of 
each individual's life, with greater social participation and complete sense of citizenship. In this sense, epidemiological aspects related to the prevalence of chronic non-communicable diseases, to the (un)healthy ways of life and the low quality of life of the populations were considered for the formulation and implementation of PAS created by the Ministry of Health (MS). The PAS was also based on successful experiences of PA practices in the community context, which emerged in some Brazilian cities since the $1990 \mathrm{~s}^{3}$.

Belo Horizonte is one of those cities. Being it the third biggest capital of Brazil, in the state of Minas Gerais, the Academia da Cidade. Program or Sports Centers of Town, as it was called at the time, was created in 2005 and aimed to promote healthy lifestyles (healthy eating and PA). The program arose from an intersectoral action, with the participation of the departments of health, food and nutrition security, education and sport, in addition to a partnership with the Federal University of Minas Gerais (UFMG) ${ }^{4}$. Currently, there are 73 PAS units within the municipality, which has the largest number of Academias da Saúde (AS), or Health Sports Centers in Brazil ${ }^{5}$.

The PAS in Belo Horizonte, supported by the Ministry of Health since 2011, is in line with one of the main axes of the National Health Promotion Policy (PNPS), to promote healthy lifestyles ${ }^{6}$, as well as with the strategic action plan for coping with Chronic Non-Communicable Diseases (DCNT) in Brazil in 2011-2022,through the developing of actions aimed mainly at controlling and reducing the risks of $\mathrm{DCNT}^{7}$.

The actions developed in these sports centers are mostly related to the axis of body practices and PA (98.6\%), being carried out by physical education professionals (PEP) (90\%) from the Extended Family Health Center in Primary Care (NASF-AB) 6 . It is one of the specific programs funded by the end of 2019 by the Ministry of Health through the variable Primary Health Care (PAB). However, in November 2019, the new funding for Primary Health Care (PAB) was published in a Regulatory Ordinance, entitled the Previne Brasil Program (PPB), which extinguished the transferring of funding to the NASF- $\mathrm{AB}^{8}$, therefore resulting in the weakening of health care actions, and consequently in the program.

Several studies have assessed the PAS on aspects ranging from the implementation of the program, monitoring, description and characterization of actions, to others related to its effectiveness, work process, quality of life, level of physical activities and user perception, professional performance, adherence among others 9 . However, there is a need to discuss this new funding and its possible effects on the development of health promotion actions, more specifically on the program. In this sense, this study aims to understand the meaning of PA and the PAS from the user's point of view, to reflect on the consequences of PPB in the structuring and functioning of the program. This is a fundamental debate for the development and sustainability of this public policy.

\section{Methods}

This is a qualitative approach study, which deepens the understanding of a social event based on the individual's experiences; the interpretation and meaning given by them are expressed in their actions and words, as representations ${ }^{10}$. These representations are structured in psychosocial processes and supported by previous ones which are deeper than the new object, but also by new knowledge and contexts, reflecting in the way individuals incorporate social values across their individuality in daily practices ${ }^{11}$, including health care. The theory of social representations (RS), in the sociological constructivist perspective proposed by Giami \& Veil ${ }^{11}$, allows the understanding of a certain object from the individual's point of view about situations that are part of their daily life.

The present study was conducted by interviewing users at the ASs in Belo Horizonte, Minas Gerais. Two ASs were sorted out from the nine regionals in the municipality.

Interviews were carried out with users at the sports centers based on an initial invitation to those present, before or after their activities, being so-called "classes". People from different age groups (18 to $30 ; 31$ to $50 ; 51$ to 65 and 65 years of age and over) and gender were also invited, with four users in each region, chosen randomly, seeking to include the demographic and social diversity of the city. Moreover, participants had to to be under the following criteria to participate in this study: be over 18 years of age, have availability for the interview and fully consent to it. The data saturation criterion was considered for completion of the collection ${ }^{12}$. For its achievement, a preliminary analysis of the interviews was carried out in the course of the collection, defined by the repetition of the subjects treated and the ways of thinking, including their contradictions, as well as the density of reflections, when new information and points did not add new data to the research. Saturation was verified by 
totaling 33 interviews out of the 36 initially planned.

Firstly, data collection took place by introducing the object of study and identifying the participants'socioeconomic situation. Then, through an in-depth interview with open, non-directive guiding questions beginning with: "Tell me what you think about: 1/physical activity, $2 /$ health academy, $3 /$ health promotion policies". Deflective questions were included to deepen some subjects and bring up representations on the topics covered, when necessary. The interviews were conducted by trained researchers, belonging to the Center for Research and Studies in Collective Health - NUPESC - of the Nursing School from Universidade Federal de Minas Gerais (UFMG).

After their transcription, the interviews were analyzed using the Narrative Structural Analysis (NSA) method, proposed by Demazière \& Dubar ${ }^{13}$, who considers that everything makes sense in the individual's speech, as the narrative presents disjunctions and conjunctions of their world views and experiences. The narrative interpretation took place in two axes, a horizontal one projected on the vertical axis, going from one level to another, once the meaning of the narrative is not at the end of the discourse, but in its entirety ${ }^{14}$.

Thus, the analysis was organized in four stages ${ }^{15}$. In the first, the vertical reading, the global meaning of the interview was sought and in the second stage, the horizontal reading, the 'deconstruction'was performed by sequencing the narrative of each interview. The sequences (S) were numbered in ascending order and, in each, the narrated facts $(\mathrm{F})$, the justifications (feelings) $(\mathrm{J})$, and the personalities or institutions $(\mathrm{P})$ involved were identified. The sequences correspond to statements about a central idea, which appear throughout the narrative, at different times, as the narrator presents new arguments and reports other facts for the same central idea. Then, each interview was reconstructed, with the sequences grouped by subject, constituting empirical categories, with provisional naming by the researcher to explain the meanings around the objects of each narrative. In the third stage, a cross-sectional reading was carried out, bringing together the set of interviews, by the categories found in each one, resulting in the conclusion of the categories and explanation of the deep representations and the most superficial representations ${ }^{11}$. In the fourth stage, a "theorization" was performed, through the interpretation and reconstruction of the categories that emerged in the analysis from the theoretical reflections of the researchers and findings of other authors.
Subsequently, an analysis of the Portaria (Regulatory Ordinance) 2,979/2019 was performed, instituting the PPB by establishing a new PAS financing model within the scope of the Unified Health System (SUS) ${ }^{7}$ to compare the results of the interviews, in order to reflect on the possible impacts of this new form of funding the functioning of the PAS.

This study was approved by the UFMG Ethics Committee, opinion no. 501.086, CAAE: 22383013.6.0000.5149, and is part of a larger project entitled "Academia da Saúde: Evaluation of Physical Activity Programs in Brazil", approved by the Ethics Committee of Federal University of Pelotas, opinion No. 151.238, CAAE: 03192412.4.1001.5313.

\section{Results}

Intervention with 33 users of ASs took part in this study. Gender balance was sought during the data collection process, but there was a female predominance, corresponding to $66.6 \%$ of the users. It reflects data from the Belo Horizonte Municipal Health Department, which shows the hegemony of the female gender participation in activities. In December 2013, the sports centers had 24,533 users, $87.6 \%$ women and $12.4 \%$ men, in the municipality (verbal information provided by the PAS Pedagogical Coordinator, in a data collection meeting).

Study participants were of different age groups, distributed as shown in Table 1.

Table 1 - Age distribution and sociodemographic characterization of participating users

\begin{tabular}{lc}
\hline \multicolumn{1}{c}{ Variables } & $\%$ \\
& $(\mathrm{n}=33)$ \\
\hline 18 to 30 years old & 12.1 \\
31 to 50 years old & 33.3 \\
51 to 65 years old & 27.3 \\
Females & 66.6 \\
High School graduate or incomplete Primary School & 57.5 \\
Common Law Marriage & 60.6 \\
Family income up to 3 minimum wages & 51.5 \\
Started joining PAS because of a health care professional & 42.4 \\
indication & \\
Started joining PAS because of a family member or neighbor & 57.6 \\
\hline
\end{tabular}

The qualitative analysis revealed that there are profound representations about PA as a "remedy" for diseases (musculoskeletal and cardiovascular) and psychosocial suffering (depression, low self-esteem and loneliness), being it a possibility to improve quality 
of life. In this sense, PA in the context of the PAS is configured, for these individuals, as a care capable of improving health, social interactions and quality of life, through free access to quality PA. It is, therefore, a necessary and inclusive health promotion policy. Users' representations of PA and PAS are expressed in their narratives and outlined in Figure 1.

Users understand PA as something positive and necessary that brings more quality to their lives because it is capable of reducing physical pain and even the use of drugs for the control of DCNTs, even for those who do not consider it as something pleasurable.

"I took a lot of medicine for my spine. After the sports centers, it got better. After I came here, I improved 50\%. My day-to-day got better. And in my profession, my performance was much better (U11, Male, 40 years old).

Actually, I don't really like [coming here]. It is so tiring! But I do it because it is like a medicine that will bring me some benefit. I know that this will give me a quality of life on going forward (U15, Female, 52 years old).

For the participants in this study, the program is also essential for introducing and maintaining healthy lifestyles.

When I first came here, I weighed 97 kilos. I lost 22 kilos, then afterwards I got "fat" again, but here we are, right? (...)My self-esteem got better. This is very important in my life (U17, Female, 34 years old).

Physical activity helps me lose weight. The program also helps us to get along with the staff. We come here, socialize, talk and stuff. I am an outgoing person, I am very home-staying, this is therapy for me! (U26, Male, 56 years old).

The representation is that PA contributes to having more physical disposition and performing daily activities, as something that is built on a daily basis. However, it goes beyond physical and biological aspects, as it is also recognized as a possibility of developing social interactions, reducing loneliness and improving self-esteem.

I love doing physical activity. It seems that we get more into it. The day you do physical activity, you have more energy for everything. Perfect! (U2, Female, 51 years old). Physical activity made me have more friends. I was more open about life, about people. I felt very stuck just in that little piece of the house and everything. Service, work, service, service. Not now. I feel it more like this:
I go, I can, I want (U1, Woman, 50).

Social interactions established by the program constitute a more comprehensive social network and more solid relationships, remaining outside it and are part of the users' lives, providing new experiences.

Because the sports center ... people come here, they destress, they relate to each other, they laugh, they play ...They let go. Here I made a friend and we already traveled together on Carnival. Me and my husband, her and her husband... We became friends (U32, Woman, 58 years old).

Participation in activities are considered important, also because professionals who work locally are seen as capable of establishing relationships of trust, with interactions that provide users with feelings of welcoming and respect.

We come here [at PAS] and are always treated well, you know? All my instructors, from the beginning until now, all were good, holy mother! Very cool! They treat me very well (U30, Female, 67 years old).

The instructors are, well, too attentive. They seek to know what is happening, why you are like this or that ... They welcome you! They are very affectionate (U1, Female, 50 years old).

For the interviewees, the PASs democratizes access to quality and have supervised PA. The indication of a health professional or of relatives and friends, the proximity of the center to the user's residence, and, mainly, the gratuity of the program were the arguments presented by the users for attending the PASs.

[The Program] is important because it brought a lot of people who ... had no possibility ... they could not pay (U27, Male, 68 years).

I see it as a very large opening for the general population. Because, sometimes, I can afford a gym, but there are people who can't afford it, just like my mother. My mother is unable to afford a gym (U10, Female, 29 years old). I had no other option. Because of time and even financial issues. And then it became an option, it matched. hub? I live near here and that was very good. As they say, it came in handy, right?! (U19, Male, 40 years old).

Users are building representations about the pro- 

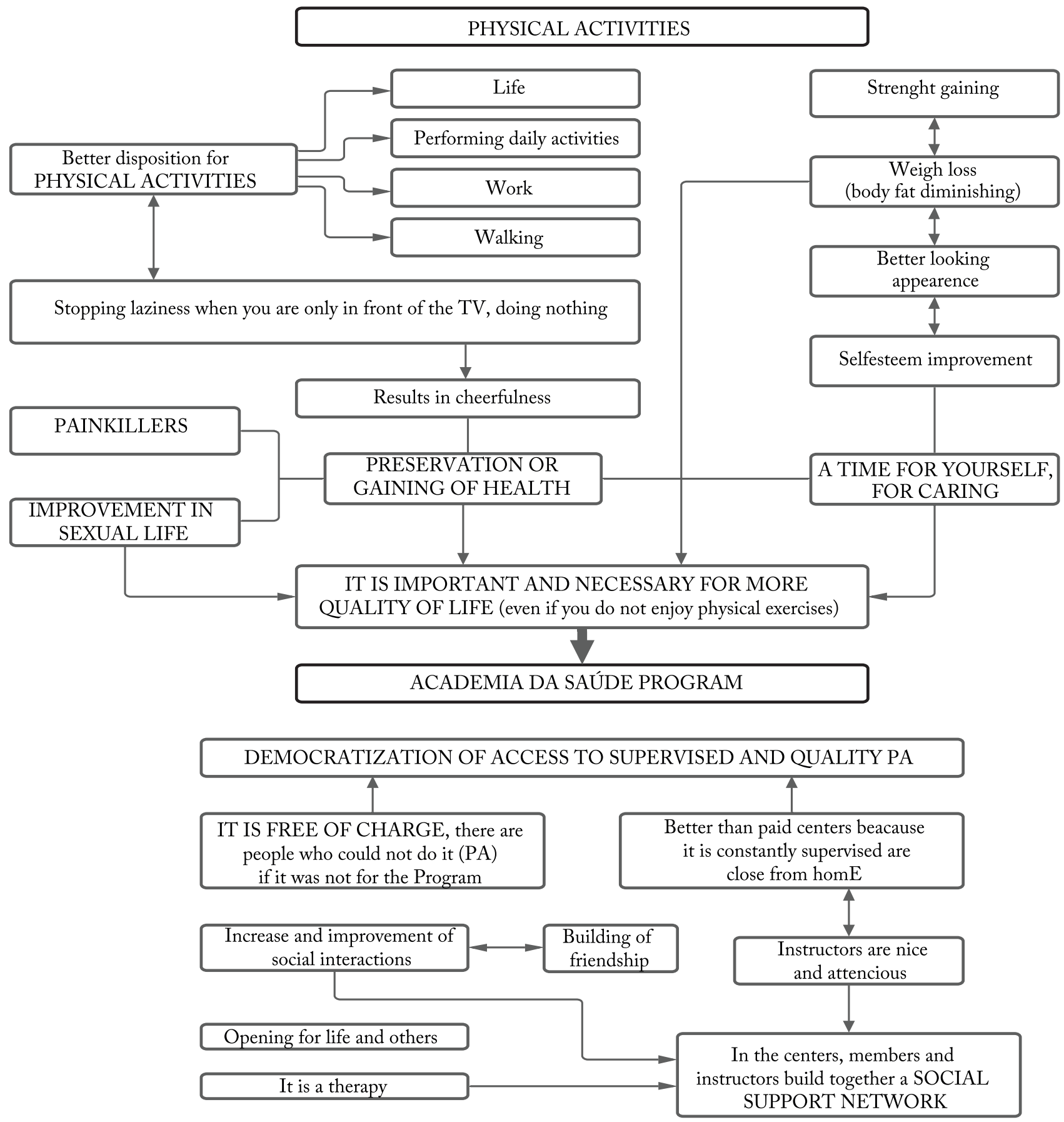

Figure 1 - Users representations about PA and PAS

gram, taking into account that the activities developed serve people of all ages, even though "it is thought that there is a greater participation of elder individuals". In addition, users questioned other people who believe that because it is free, the sports centers have no quality:

There are people who think that because it is free, then it sucks. A neighbor, an acquaintance who asks about it ... But the love that comes from my mother ... my wife, my daughter is free. So, it makes me live! Just because it's free, is it worthless? This concept has changed a lot. I hope it changes even more (U11, Male, 40 years old).

From the main aspects that concern the representations of PASs users about the Program and about PA, it can be said that these are under construction, shared by those who attend the activities. Although in social relationships, there are questions about the quality by 
neighbors or acquaintances. This construction of representations by users shows the importance of PAS for health promotion, as shown in Figure 2.
New Funding of APS

In November 2019, the Ministry of Health published the Portaria (ordinance) 2,979, instituting the Previne Brasil Program and bringing changes to the PHC

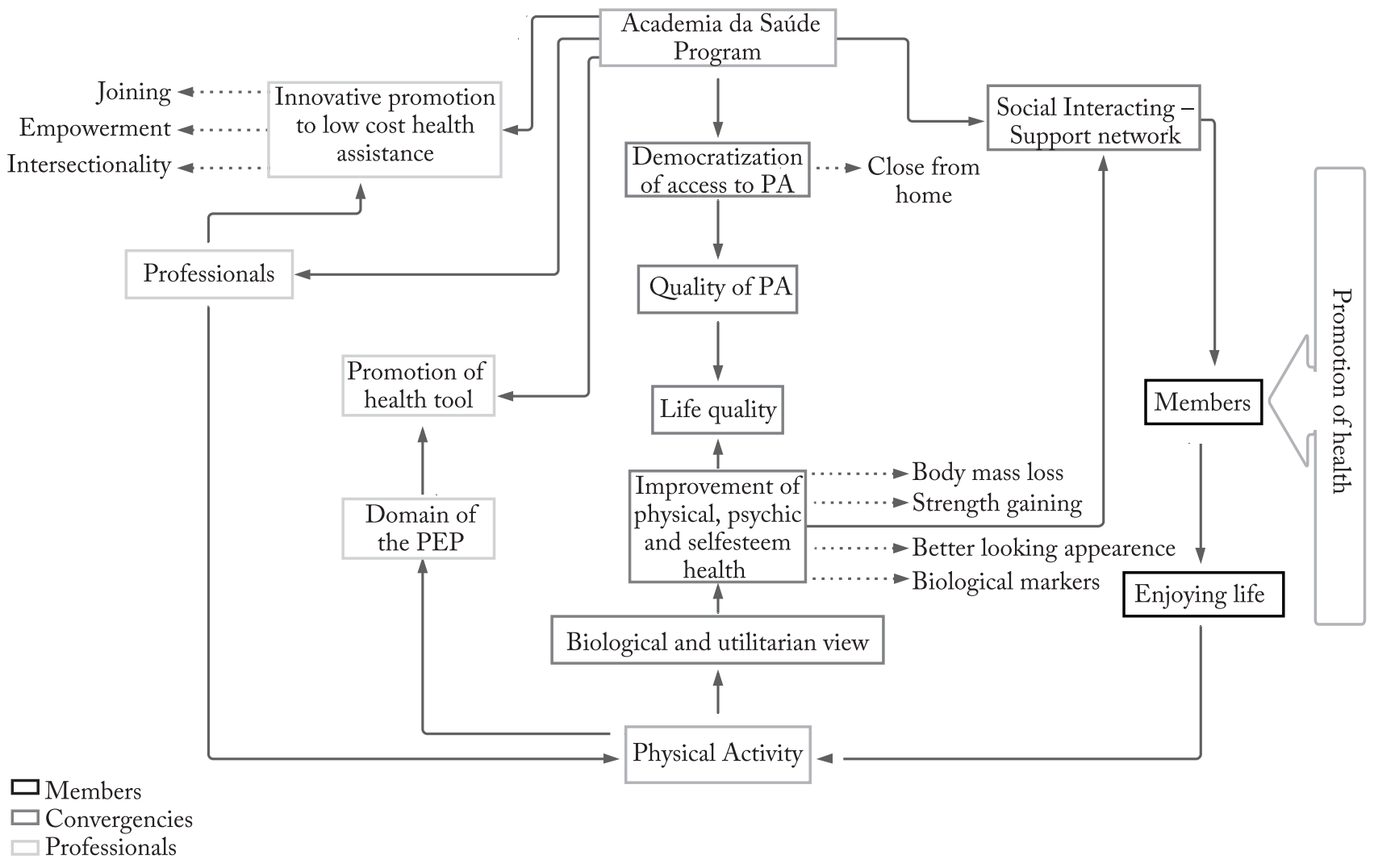

Figure 2 - Interpretative model of PAS members' representations about the Program and about PA in this context

Chart 1 - Main changes in Primary Health Care financing, with the decision contained in Portaria 2,979, of December 10, 2019 , from MS.

\begin{tabular}{ll}
\hline Resources & Prior funding models (fixed and variable PAB) ${ }^{16}$ \\
\hline Per capita resources & $\begin{array}{l}\text { Transferring of resources according to the population defined } \\
\text { by IBGE }\end{array}$
\end{tabular}

Resources conditioned to the implementation of Primary Care strategies and programs
Transferring of resources conditioned to the implementation of different teams: Family Health, Primary Care, Oral Health, Community Health Agents, Consultorio nas Ruas, Rivers and Riversides Family Health and NASF-AB, in addition to the Health at Schools and Health Academy Programs

Current funding model (Previne Brasil Program) ${ }^{17}$

Weighted capitation: Transferring of resources based on the number of registrations made by the Family Health Teams or Primary Care teams

Conditioned to adherence to the following specific actions and programs: Saúde na Hora, Oral Health Teams, Mobile Oral Unit, Oral Specialties Center, Regional Dental Prosthesis Laboratory, Consultorio nas Ruas, Basic Fluvial Health Unit, Riversides Family Health Teams, Microscopist, Prison Primary Care Teams, Family Health Teams and Primary Care Teams that assist teenagers in conflict with the Law, Health at Schools Program, Health Academy Center, Computerization of staff, Funding to municipalities with Medical and Multi-professional Residency

Transferring of resources subject to adherence and performance in the National Program for the Improvement of Access and

Resources conditioned to the performance of Primary Care services Quality of Primary Care that aims to induce the institution of processes that expand the capacity of Federal, State and Municipal administrations, in addition to the Primary Care Teams, to offer services that ensure greater access and quality, according to the specific needs of the population
Funding for reaching defined goals for 21 team performance indicators.

Font: Portaria No. 2,436, from September 21, 201716 and Secreteriat of Primary Health Care ${ }^{17}$.

$\mathrm{PAB}=$ Primary Health Care; IBGE - Brazilian Institute of Geography and Statistics - IBGE; NASF-AB = Extended Family Health Center in Primary Care; MS = Ministry of Health. 
funding model, within the scope of SUS, modifying the Federal Government's commitment to Brazilian municipalities regarding the action's health promotion. Chart 1 shows the main differences between the model at the time the program was implemented ${ }^{16}$ and the current financing of the APS ${ }^{17}$.

It is observed that the Federal funds destined to fund APS shares were until 2019, transferred from the $\mathrm{PAB}$ and divided into two funding blocks: Fixed $\mathrm{PAB}$, based on the per capita value, and Variable PAB, conditioned on joining on specific programs, including $\mathrm{NASF}-\mathrm{AB}^{16}$.

\section{Discussion}

Although regular PA practice is important, the number of sedentary people is high in Brazil and in the world $^{18-20}$. Factors such as quick and easy access, in addition to specific interventions, have been described as facilitators for joining regular PA practices ${ }^{21}$. Access to PA practice and free PASs, together with the quality of the service provided and proximity to home were the aspects found in the present study, that most favored the participation and the joining of users to it. In another study, factors such as lack of company, tiredness and lack of motivation were identified as barriers to the practice of $\mathrm{PA}$ in $\mathrm{PASs}^{22}$. Social interaction within the centers is of great importance, configuring the AS as a valuable point of support within the health care network. It is expected that, when establishing these social support networks, users are subject to better health conditions ${ }^{23}$.

This study highlighted that participation in PASs increases the personal motivation of users to improve their diet and have a more active life, extended to the family, reinforcing the importance of health interventions in a broader way, as proposed in the PASs guidelines. These representations are in line with other studies that showed a positive relationship between the practice of PA and the adoption of healthy lifestyles ${ }^{24,25}$.

Users representations of PA and PASs have historically and culturally constructed foundations based on a stronger basis in the biological sciences. However, there is a considerable advance of these individuals who see the PASs as a public health promotion policy in a broader sense, as they relate the practice of PA to the benefits of physical and physiological order, but also to those of psychic and social order. When reporting the importance of the Program, its free access and the need for its continuity, individuals are exercising their full cit- izenship and appropriating a space that is in their right.

In this sense, the PPB has been questioned ${ }^{26,27}$, as it extinguishes the $\mathrm{PAB}$ in its fixed and variable version. Such proposal does not include, in any of the components mentioned, a specific funding transferring for maintenance of the NASF-AB teams. Additionally, it revokes the ordinances that regulate such strategy, letting off municipal managers to compose the teams with the parameters of multiprofessional performance. These parameters had been designed to expand the scope of actions of the eSF. With the new model, it tends to evolve towards a composition based only on doctors and nurses in compliance with the eligible indicators for funding, as defined by the Ministry of Health, once it is closest to the scope of these professionals' actions related to performance ${ }^{7,26}$. There is only one indicator in PHC that includes the intention to stimulate the performance of other professional categories (multiprofessional actions).

Considering that the actions developed in the PASs are linked to the work of the NASF-AB teams, even if there are no differences in funding for PAS or PPB, users are subject to losing this important space for care and health. The insufficient detailing of multiprofessional action indicators brings many uncertainties regarding the diversity of categories to be considered by the Ministry of Health for funding purposes. Such uncertainties can be considered as a threat to public health, as they differ with the strategy used until then, being more aligned with the model recommended by $\mathrm{SUS}^{27}$. The new model proposed by PPB may cause a limitation for the development of health promotion actions, one of which is PA. The PPB proposes that health managers choose whether or not to encourage the inclusion of physical education professionals, for example, in the local health care model, as the new strategy allows any formatting of the multidisciplinary team to be adopted, including none ${ }^{17,28}$. Integrating the NASF-AB team with PASs would be an alternative, since the Program is included in Previne Brasil. Thus, this equipment could be understood as an ideal space for the performance of these professionals, thus ensuring the promotion of PA in PHC, even without the presence in the Basic Health Units through the NASF-AB.

The present study revealed that public policies such as the PASs, which includes oriented PA by PEP, have favored users' understanding of the health-disease process in a health promotion model that seeks empowerment of individuals, without strict prescriptions 
and supported by representations, being built socially, with integral care. and autonomy for healthy lifestyle choices. However, the 2019 PPB may result in PASs setbacks, which will affect all primary care with regard to health promotion practices by reducing it. The results of this study should be considered by municipal managers when establishing the formation of their multiprofessional teams. It is necessary to deepen this discussion based on research that includes users participating in other health promotion actions developed by the municipality.

\section{Conflict of interest}

The authors declare no conflict of interest.

\section{Fundings}

This study was supported by grants from the National Council of Scientific and Technological Development - CNPq, Brasília, Brazil (Productivity research grants \# 552752/2011-8).

\section{Authors' contribution}

All authors have made substantial contributions to the conception and design of the study. Ivo AMSI and Freitas MIF were involved in data collection, interpretation and analysis, the conception of the manuscript, drafting it and critically revising it. Viana, VC was involved in drafting and revising the manuscript, and all have given final approval of the version to be published.

\section{Acknowledgments}

We would also like to thank the Núcleo de Pesquisas e Estudos em Saúde Coletiva (NUPESC)- UFMG; Grupo de Estudos em Epidemiologia da Atividade Física - UFPel.

\section{References}

1. Brasil. Portaria 1401 de 15 de junho de 2011. Institui, no âmbito da Política Nacional de Atenção Básica, o Incentivo para construção de Polos da Academia da Saúde. Diário Oficial da União. 2011.

2. Almeida AR, Athayde FTS. Promoção da saúde, qualidade de vida e iniquidade em saúde: reflexões para a saúde pública. Tempus Actas Saúde Colet. 2015;9(2):165-72.

3. Brasil. Secretaria de Vigilância em Saúde. Departamento de Análise de Situação em Saúde. Avaliação de efetividade de programas de educação física no Brasil: 2013. 1th ed. Brasilia: Núcleo de Comunicação/GAB/SVS; 2015 [citado em 2019 Set 20]. Disponível em: http://bvsms.saude.gov.br/bvs/publicacoes/ avaliacao_efetividade_programas_atividade_fisica.pdf

4. Lopes A, Ferreira A, Mendonça R, Dias MA, Rodrigues R, Santos L. Estratégia de Promoção à Saúde: Programa Academia da Cidade de Belo Horizonte. Rev Bras Ativ Fis Saude. 2016;21(4):379-84.
5. Brasil. Secretaria de Vigilância em Saúde. Departamento de Vigilância de Doenças e Agravos não Transmissíveis e Promoção da Saúde. Panorama nacional de implementação do Programa Academia da Saúde: monitoramento nacional da gestão do Programa Academia da Saúde: ciclo 2016: 2017. 1th ed. Brasilia: Ministério da Saúde; 2017 [citado em 2019 Out 16]. Disponível em: http://189.28.128.100/dab/ docs/portaldab/documentos/panorama_nacional_academia_ saude_2016.pdf

6. Brasil. Portaria 2.446 de 11 de novembro de 2014. Redefine a Política Nacional de Promoção da Saúde (PNPS). Diário Oficial da União. 2014.

7. Brasil. Portaria no 2.979, de 12 de novembro de 2019. Institui o Programa Previne Brasil, que estabelece novo modelo de financiamento de custeio da Atenção Primária à Saúde no âmbito do Sistema Único de Saúde, por meio da alteração da Portaria de Consolidação no 6/GM/MS, de 28 de setembro de 2017. Diário Oficial da União. 2019.

8. Guerra PH, Andrade DR, Rodriguez-Añez CR, Santos DL, Camargo EM, Fermino RC, et.al. Research on the Academia da Cidade and Academia da Saude Programs: scoping review. Rev Bras Ativ Fís Saúde. 2020;25:e0126.

9. Maciel GM, Saraiva LAS, Silva MM, Vieira Junior PR. Performance evaluation of the health gym program in Belo Horizonte: a case study. Movimento. 2019;25:e25026.

10. Minayo MCS. Análise qualitativa: teoria, passos e fidedignidade. Ciênc Saúde Colet. 2012; 17(3): 621-6.

11. Giami A, Veil C. Enfermeiras frente à aids: representações e condutas, permanência e mudanças. Canoas: ULBRA; 1997.

12. Fontanella BJB, Ricas J, Turato ER. Amostragem por saturação em pesquisas qualitativas em saúde: contribuições teóricas. Cad Saúde Pública. 2008;24(1):17-27.

13. Demaziere D, Dubar C.Analyser les entretiens biographiques: I'example de recits d'insertion. Paris: Nathan; 1997.350 p.

14. Barthes R. A aventura semiológica. 1st ed. São Paulo: Martins Fontes; 2001. 1, Introdução a analise Estrutural da narrativa; p. 103-52.

15. Ivo AMS. Avaliação Qualitativa das Academias da Saúde de Belo Horizonte: A Ótica dos Atores [tese de doutorado]. Belo Horizonte: Escola de Enfermagem, Universidade Federal de Minas Gerais; 2019.

16. Brasil. Portaria no 2.436, de 21 de setembro de 2017. Aprova a Política Nacional de Atenção Básica, estabelecendo a revisão de diretrizes para a organização da Atenção Básica, no âmbito do Sistema Único de Saúde (SUS). Diário Oficial da União. 2017.

17. Brasil. Secretaria de Atenção Primária à Saúde. Programa Previne Brasil: Novo Modelo de Financiamento da Atenção Primária à Saúde: Brasília. 2020. [citato em 2020 jun 06]. Disponível em: http://189.28.128.100/dab/docs/portaldab/ documentos/novo_financiamento_APS_previne_brasil_ oficina.pdf

18. Brasil. Secretaria de Vigilância em Saúde. Departamento de Vigilância de Doenças e Agravos não Transmissíveis e Promoção da Saúde. Vigitel Brasil 2017: vigilância de fatores de risco e proteção para doenças crônicas por inquérito telefônico: 2018. 1th ed. Brasilia: Ministério da Saúde; 2018 [citado em 2019 Out 24]. Disponível em: http://bvsms. saude.gov.br/bvs/publicacoes/vigitel_brasil_2017_vigilancia_ fatores_risco.pdf

19. Hallal PC, Andersen LB, Bull FC, Guthold R, Haskell W, Ekelund U. Global physical activity levels: surveillance progress, pitfalls, and prospects. Lancet. 2012;380(9838):247-57. 
20. World Health Organization (WHO). Global action plan on physical activity 2018-2030: more active people for a healthier world. Geneva: WHO; 2018. [citado em 2019 Out 10]. Disponível em: https://apps.who.int/iris/bitstream/hand le/10665/272722/9789241514187-eng.pdf?ua=1

21. Kelly S, Martin S, Kuhn I, Cowan A, Brayne C, Lafortune L.. Barriers and Facilitators to the Uptake and Maintenance of Healthy Behaviours by People at Mid-Life: A Rapid Systematic Review. PLoS One. 2016;11(1).

22. Gomes GAO, Papinib CB, Nakamura PM, Teixeira IP, Kokubund E, et al. Barreiras para pratica de atividade física entre mulheres atendidas na Atenção Básica de Saúde. Rev Bras Ciênc Esporte. 2018;41(3):263-70.

23. Santos WJ. Redes sociais na experiência de mulheres em situação de violência perpetrada por parceiro íntimo [tese de doutorado]. Belo Horizonte: Escola de Enfermagem, Universidade Federal de Minas Gerais; 2018.

24. Loch MR, Bortoletto MSS, Tanno de Souza RK, Mesas AE. Simultaneidade de comportamentos de risco para a saúde e fatores associados em estudo de base populacional. Cad Saúde Colet. 2015;23(2):180-87.
25. Naughton P, Mccarthy SN, Mccarthy MB. The creation of a healthy eating motivation score and its association with food choice and physical activity in a cross sectional sample of Irish adults. Int J Behav Nutr Phys Act. 2015;12(1):01-10.

26. Giovanella L, Franco CM, De Almeida PF. National primary health care policy: Where are we headed to?. Ciênc Saúde Colet. 2020;25(4):1475-82.

27. Stevanin, L. F. Previne Brasil: Mudança sem debate. [publicação online]; 2019 [acesso em 24 mai 2020]. Disponível em: https://radis.ensp.fiocruz.br/index. $\mathrm{php} /$ home/reportagem/previne-brasil-mudanca-semdebate\#access-content

28. Brasil. Nota Técnica no 3 de 28 de janeiro de 2020. Núcleo Ampliado de Saúde da Família e Atenção Básica (NASF-AB) e Programa Previne Brasil. Diário Oficial da União. 2020.

Received: 30/07/2020

Approved: 25/11/2020

\section{Quote this article as: \\ Ivo AMS, Viana VC, Freitas MIF. Health Academy Program: importance for users and funding diffuculties. Rev Bras Ativ Fís Saúde. 2020;25:e0169. DOI: 10.12820/rbafs.25e0169}

